\title{
Database of the historical series of fisheries production in the middle Madeira River region, southwest of the Amazon, from 2001 to 2013.
}

Recebido: 27/07/2021 | Aceito: 28/10/2021 | Publicado: 15/11/2021 https://doi.org/10.53805/lads.v1i2.27

\author{
Keythiane F. Ramos ${ }^{1}$, Larissa S. Pelegrini ${ }^{*}{ }^{1}$, Jéssica V. Sardinha ${ }^{1}$, Rodrigo Tartari ${ }^{2}$, Marcelo R. dos Anjos ${ }^{1}$
}

\section{ABSTRACT}

The Amazon is very important regarding the continental extractive fishing as it has the greatest diversity of freshwater fish in the world. Some factors can contribute to identify significant changes in fish production, such as characterization based on common names, and synonyms or classifications only at the genus level. This creates noise in different types of analyzes and mistakes in determining effective productions, as well as levels of exploitation for management. Thus, this study aims to demonstrate the variation in fish production over the years 2001 and 2013, using control data from the fishing colony "Dr. Renato Pereira Gonçalves Z-31" in the municipality of Humaitá, southern Amazonas. These data were analyzed by collaborators from the Laboratory of Ichthyology and Fisheries Management of the Madeira River Valley, at the Federal University of Amazonas. The fish landing monitoring allowed the determination of the species caught in the regional fishery and evaluated the effect of the hydrological level and the pre- and post-installation periods of the Santo Antônio and Jirau HPPs in Rondônia, on the total production. The data set showed the significant decrease in fish production between 2008 and 2013. Among the factors that explain the observed changes are the mistakes in determining the effective production due to the lack of criteria in the grouping of many species, the absence of regulations, such as the "Portaria IBAMA № 48" which was created only in 2007, in addition to the installation period of the HPPs on the Madeira River. It was also possible to verify the effect of seasonality through hydrological quotas on fish production, with the highest values observed in July, August and September of the years analyzed.

Keywords: Fishery production, Middle Madeira River, Fisheries in southern Amazonas, Artisanal fishery data, Fishing management.

\footnotetext{
1 Universidade Federal do Amazonas (UFAM), Laboratório de Ictiologia e Ordenamento Pesqueiro do Vale do rio Madeira (LIOP), Humaitá, Amazonas, Brazil. biolarapelegrini@gmail.com.

2 Universidade Estadual de Maringá (UEM), Departamento de Meio Ambiente (DAM). Umuarama, Paraná, Brazil.
} 


\section{DATA IMPORTANCE}

- The fishing activity is one of the main efforts to obtain samples for the study of fish populations, especially for the Amazon region, providing information on their biology and environmental data, especially on capture environments.

- Small-scale artisanal fishing in the middle Madeira River region and its relationship with the dynamics of these environments is still little known and little explored by researchers in general. This makes it essential to produce information that serve as a basis for organizing a database that provides information about spatial/temporal distributions, as well as the ecological variances of the correlated environments.

- Another important factor is the refinement degree of the data generated for the main explored species between 2001 and 2013, which, in most cases, have their production characterized by common names, already verified by synonyms or classified only at the genus level. This generates noise in different types of analyzes and mistakes, especially, in the characterization of production levels for certain species, as well as for the determination of exploitation levels for management.

- The data can also be used to express economic and development factors for fisheries in the region, highlighting the variation in prices for different hydrological periods, which can be discussed in the future.

\section{MATERIALS AND METHODS}

\section{Study area}

The Madeira River drains three main morphostructural units: the Andes Mountains (15\%), the Amazonian craton (41\% of the basin) and the Amazon plain (44\%), with distinct lithologies and geomorphology (GUYOT et al., 2007). In the Andes Mountains region, where the headwaters of the Madeira River are located, and along most of its course, sedimentary rocks and Quaternary sediments occur, while the right bank tributaries come from Precambrian and Paleozoic igneous and (meta) sedimentary rocks of the Amazonian craton with less contribution from Cenozoic sedimentary rocks (RODDAZ et al., 2005).

Seasonal dynamics controls the physicochemical parameters, with the highest values observed for $\mathrm{pH}$ and conductivity for the drought period and with low variation in the flooding period, turbidity with higher values for the water falling transition period. Its tributaries, unlike the Madeira River, have black waters, with lower $\mathrm{pH}$ values, and consequently more acidic water, with higher values observed for conductivity and turbidity during the period of flooding or transition to drought (HORBE et al., 2013).

The data in this study correspond to the region of the middle Madeira River (between coordinates $6^{\circ} 09^{\prime} 07^{\prime \prime S}$ and 61 $47^{\prime} 21^{\prime \prime} \mathrm{W}$; $7^{\circ} 53^{\prime} 22^{\prime \prime S}$ and $\left.63^{\circ} 06^{\prime} 25^{\prime \prime} \mathrm{W}\right)$, and also lakes, "igarapés" and islands that form from it. The study area is located between the municipality of Humaitá and its mouth on the Amazon River, which comprises the tributaries Marmelos, Manicoré, Aripuanã, Canumã, on the right bank, and the Acará and Madeirinha, on the left bank. The rivers on the right bank have their sources in the states of Mato Grosso, Rondônia and southeastern Amazonas. Most of its courses drain the Amazonian craton rocks exposed along the course and intense weathering. In turn, left bank tributaries are a few kilometers long and their courses are over Cenozoic sedimentary rocks and recent sedimentary deposits (HORBE et al., 2013).

The municipality of Humaitá, where the fish landing survey was carried out, is located in the southwest of the Brazilian Amazon (Fig. 1) and in the south of the State of Amazonas. It is located on the left bank of the Madeira River and has Porto Velho, the capital of the State of Rondônia, located $200 \mathrm{~km}$ away. The main access is the 
federal highway, BR 319, which also connects to the capital of the State of Amazonas, Manaus, 675 km away. The estimated population of Humaitá for 2014 was 56,144 inhabitants, with a territorial area of $33,111.143 \mathrm{~km}^{2}$ (IBGE, 2017).

\section{Data collection}

The survey of data between the years 2001 to 2013 was carried out at the Fishermen's Colony "Z31 Dr. Renato Pereira Gonçalves", in the middle Madeira River region. The colony has about 1,500 associated fishermen and is located close to the municipal market of Humaitá. After collected, the data were scanned and organized into electronic spreadsheets for later analysis. To relate the annual fishing production with the average hydrological quotas $(\mathrm{cm})$ of the Madeira River, data were obtained from the "Portal HidroWeb v3.2.6." (SNIRH, 2021) of the fluviometric station "15630000 Humaitá" with the minimum and maximum hydrological values for the period analyzed. From this, it was possible to verify how the level of the Madeira River behaved through the monthly averages for the entire period in this study area.

The data were organized into years, months and morphotypes with popular nomenclatures used by the fishermen of Colony $Z-31$.

Figure 1. Location of fishing environments along the Madeira River Basin recorded by Fishermen's Colony "Z-31 Dr. Renato Pereira Gonçalves" during the years 2001 to 2013, southern Amazonas State, Brazil. The names of the locations corresponding to the numbers on the map are found in the supplementary file for this study.

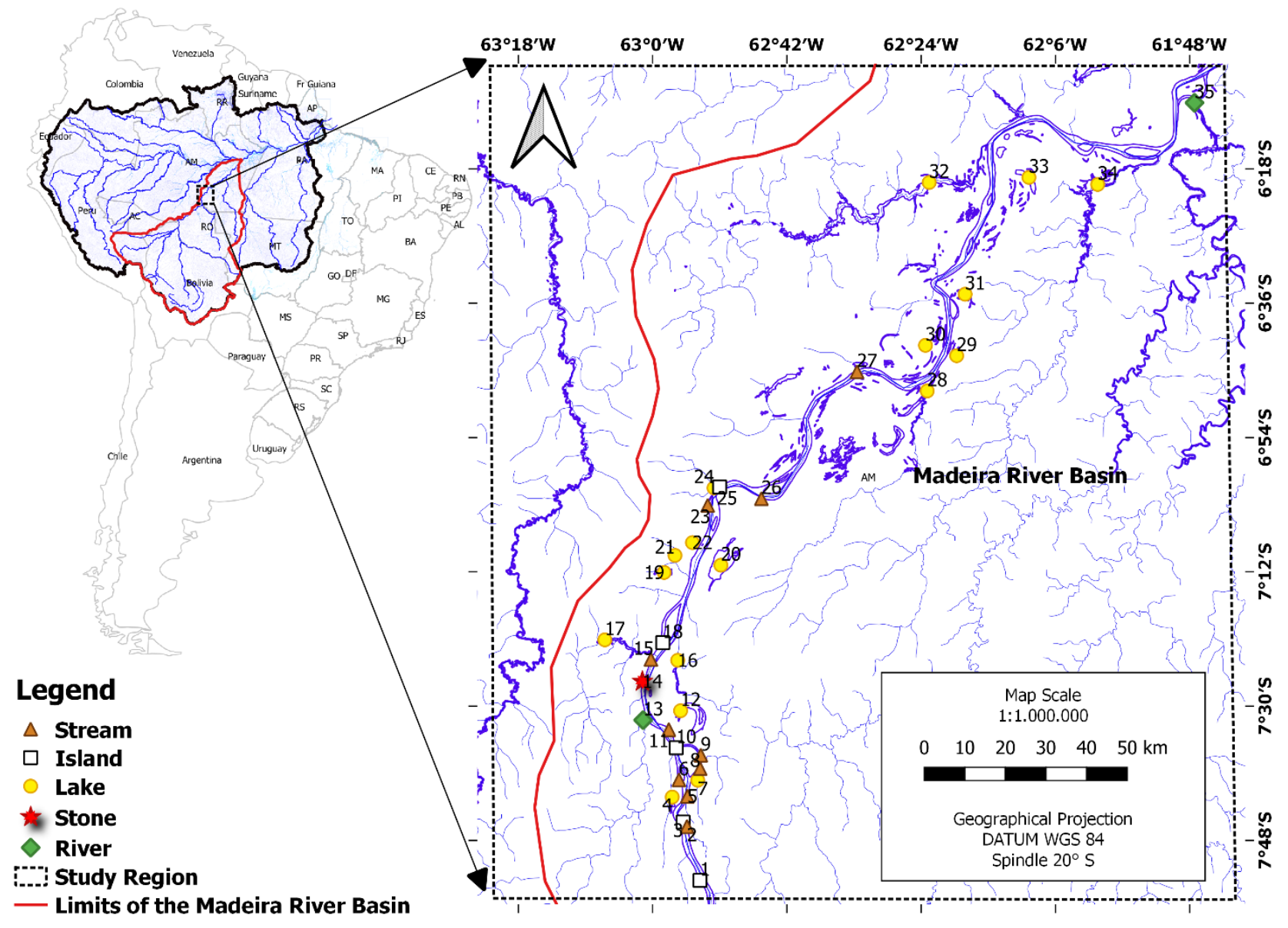




\section{DATA DESCRIPTION}

Forty-four fish morphotypes were identified in the municipality's fishing landing, belonging to the orders: Siluriformes (23), Characiformes (15), Cichliformes (3), Clupeiformes (1), Perciformes (1) and Osteoglossiformes (1) (Table 1). There was a decrease in fish production along the time gradient from 2007 onwards (Fig. 2). The differences observed between the years 20012006 and 2008-2013 are partly due to the increase in species included in the list of protected species during the closed season and the increase in inspection operations.

Another point that may be related to the decrease in fish production as of 2008 (especially for some species) is the start of construction of the Jirau and Santo Antônio hydroelectric plants (HPP), located upstream and close to the study area, where they opened in 2012 . Hydroelectric power plants are responsible for major changes in flood pulses, causing longitudinal disturbances along the river course (TIMPE; KAPLAN, 2017). The construction and subsequent operation of hydroelectric dams promote major environmental changes that can interfere with the reproductive dynamics of several fish species, modifying the abundance, composition and trophic configuration of their assemblages, including an increase in the abundance of some species, creating an environment with dominant species, while the populations of others can be drastically reduced or even extinct (AGOSTINHO et al., 2004). Most commercial fish species found in the Madeira River undertake reproductive migrations and their routes can be compromised (BARTHEM et al., 2017; SANTOS et al., 2018). As the analyzed region is located downstream of the HPP, this effect can be observed by the data presented (Fig. 2).

Figure 2. Variation in total fish production (Kg) over the years 2001 to 2013, from artisanal fishing recorded in the municipality of Humaitá, Amazonas, Brazil.

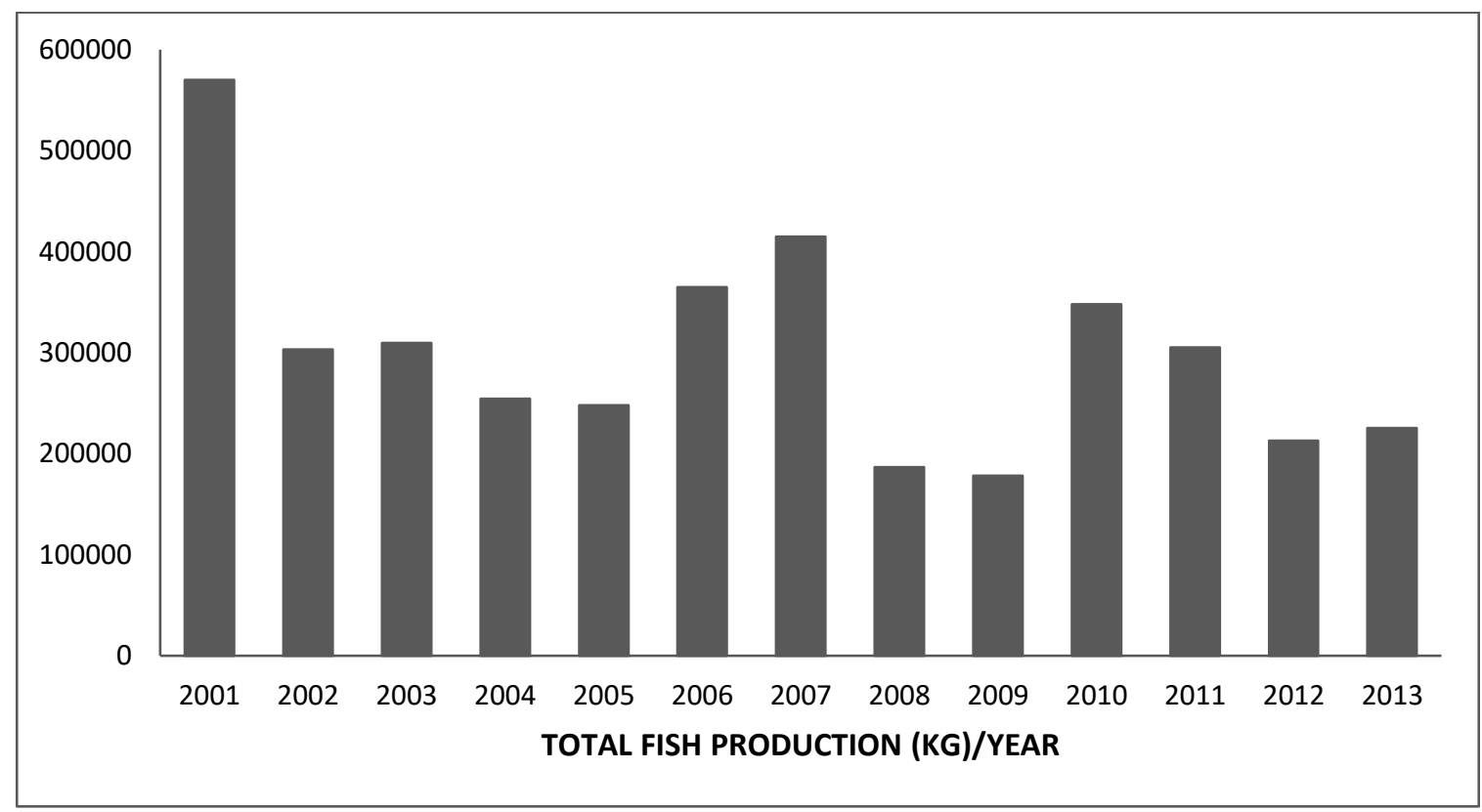

To verify the importance of the seasonal period, the influence of river volume on total production in each year was verified. In general, the highest production peaks occurred in March, April and May (flooding), and July, August and
September (lowing - drought transition) (Fig. 3 and 4). The lowest productions occurred during rising - flooding, from December to February, which can also be reinforced by the beginning of the closed season for some species. 
Figure 3. Monthly average of fish production (Kg) over the years 2001 to 2013 from artisanal fishing in the municipality of Humaitá, Amazonas, Brazil.

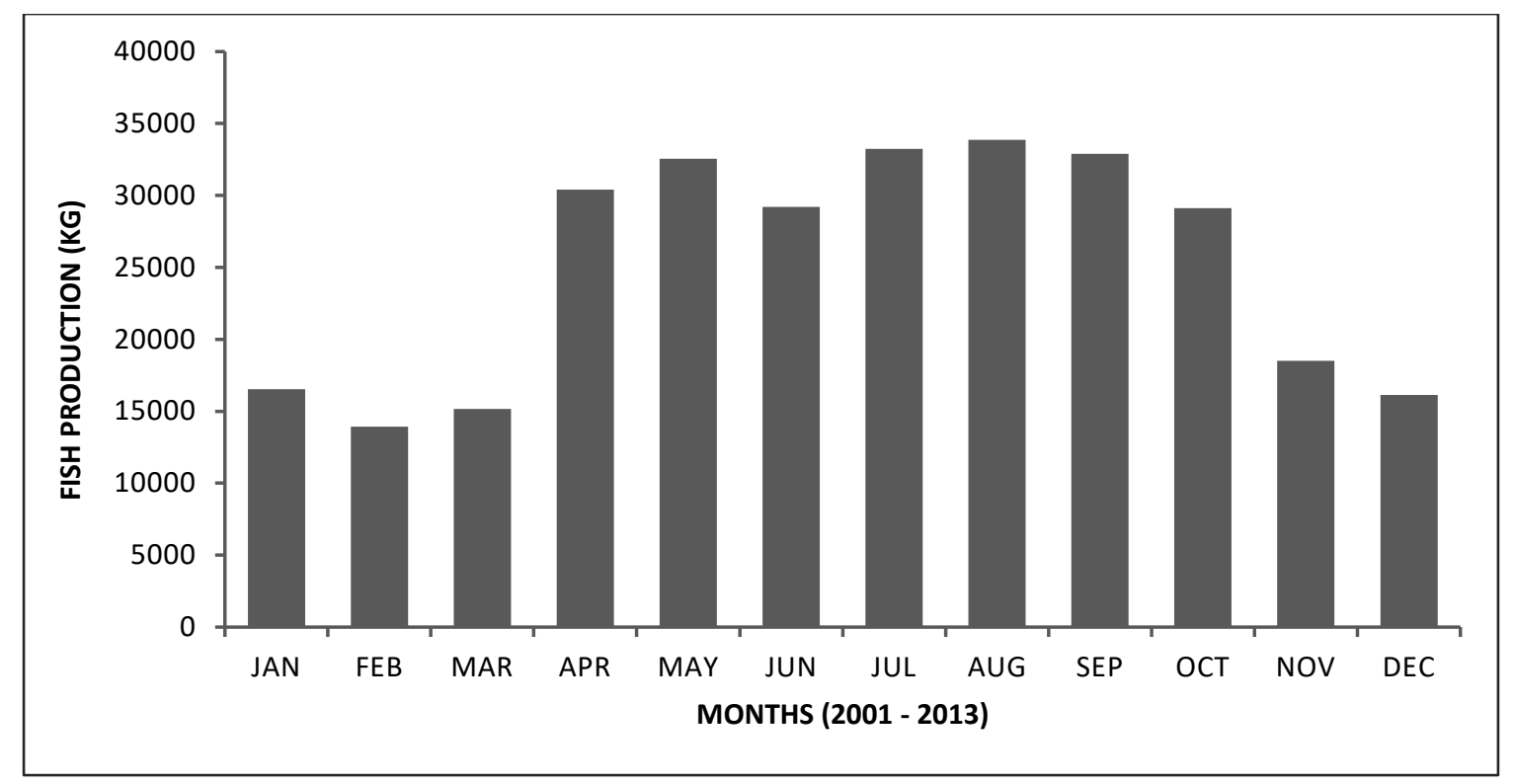

It is important to highlight that the catches of species included in the closed season predate the creation of "Portaria IBAMA № 48 " of November 5,2007 . The influence of the flood pulses is evident when analyzing the graphic of the quotas with the monthly averages of the hydrological level of the Madeira River, over the last 20 years, and its variation (Fig. 4).

Figure 4. Quotes of monthly averages of the hydrological level of the Madeira River in the region close to the municipality of Humaitá, Amazonas, Brazil, from 2001 to 2013.

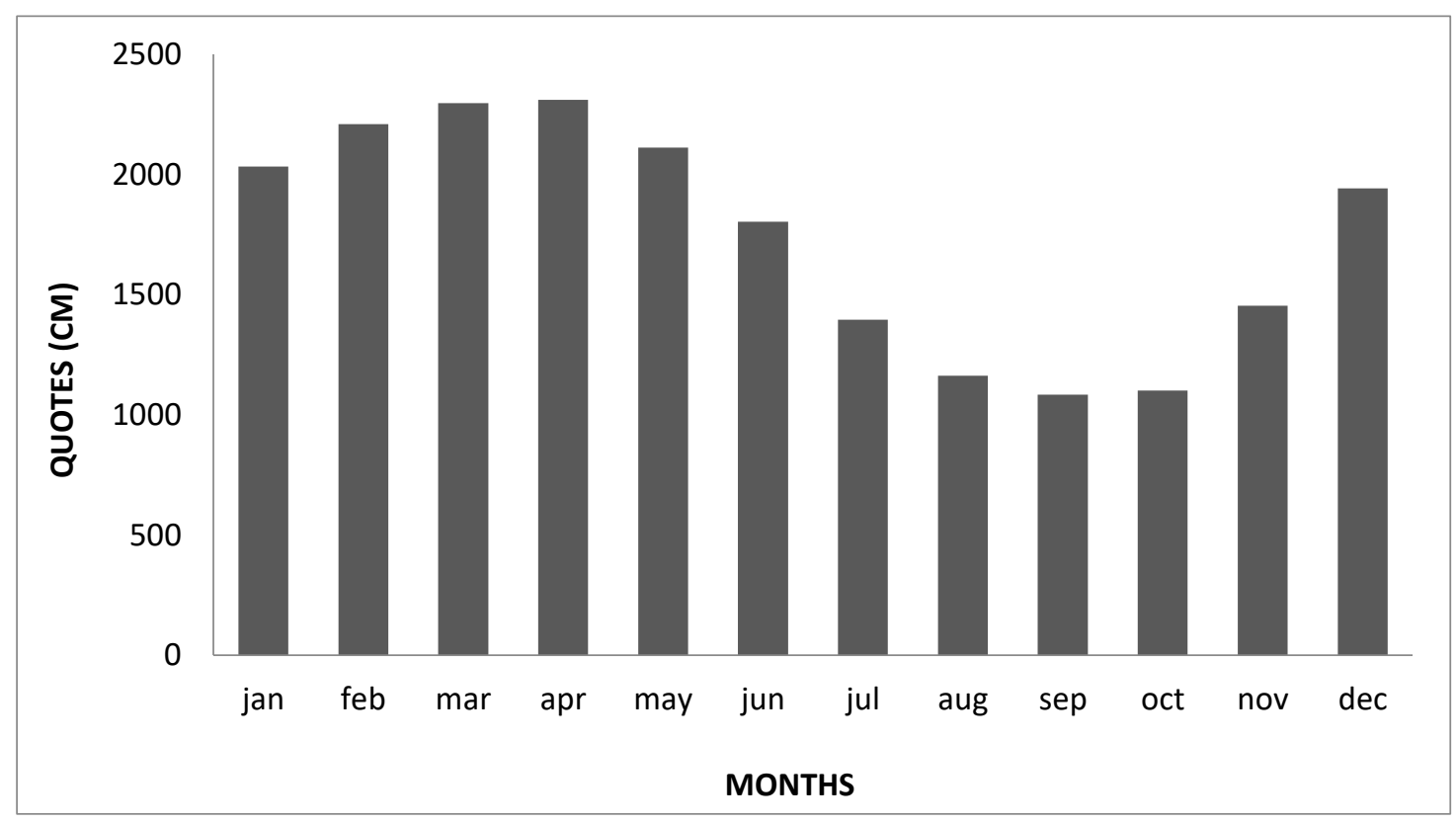

The fish with the greatest economic potential that stood out for production and stock regularity were the species belonging to the Characidae,
Prochilodontidae, and Pimelodidae, noting that "pacus and jaraquis" (Mylossoma spp. and 
Semaprochilodus spp.) were the most expressive among the groups analyzed.

Another important fact is that the "piraíba or filhote" (Brachyplatystoma spp.), a catfish of great commercial interest, had its stock drastically reduced to the point that in 2011 only $38 \mathrm{~kg}$ were accounted for in the fish landing, a fact that it deserves greater attention from regulatory agencies and especially fishermen, so that the populations of this fish can restructure themselves, avoiding local extinction.

There are also other species with great commercial value for the region that are classified as threatened with extinction, overexploited or threatened with overexploitation, such as the Pirarucu (Arapaima gigas (Schinz, 1822)) (which was not registered in the landing for the analyzed period), Tambaqui (Colossoma macropomum (Cuvier, 1816)), Piramutaba (Brachyplatystoma vailantii (Valenciennes, 1840)), Dourada (Brachyplatystoma rosseauxii (Castelnau, 1855)) and Jaú (Zungaro zungaro (Humboldt, 1821)) (ROSA; LIMA, 2008).

\section{Dataset}

The dataset for this study is available in an Excel file (supplementary file "LIOP_Dataset_desembarque2001-2013.xlsx") with 15 tabs. In 13 tabs, the production of each year was plotted, with the total $(\mathrm{kg})$ of each fish morphotype. These totals were separated by each month (12 columns).

In the penultimate tab, the morphotypes were placed with their corresponding species and their orders. Finally, the last tab shows the fishing locations reported by the fishermen and their respective geographic locations.

Table 1. Fishes registered in the fishing landing of the Fishermen's Colony Z-31 "Dr. Renato Pereira Gonçalves" in the municipality of Humaitá, southern Amazonas, from 2001 to 2013.

\begin{tabular}{llc}
\hline \multicolumn{1}{c}{ COMMON NAME } & \multicolumn{1}{c}{ SPECIES } & ORDER \\
\hline Acará & Chaetobranchus flavescens Heckel, 1840 & Cichliformes \\
& Heros spurius Heckel, 1840 & \\
Acará-açu & Astronotus crassipinnis (Heckel, 1840) & Cichliformes \\
Apapá & Pellona castelnaeana Valenciennes, 1847 & Clupeiformes \\
Aruanã & Osteoglossum bicirrhosum (Cuvier, 1829) & Osteoglossiformes \\
Babão & Brachyplatystoma platynemum Boulenger, 1898 & Siluriformes \\
Bacu & Lithodoras dorsalis (Valenciennes, 1840) & Siluriformes \\
Barbado/barba-chata & Pinirampus pirinampu (Spix \& Agassiz, 1829) & Siluriformes \\
Bico de pato & Sorubim lima (Bloch \& Schneider, 1801) & Siluriformes \\
Bodó & Pterygoplichthys pardalis (Castelnau, 1855) & Siluriformes \\
Branquinha/chora & Potamorhina latior (Spix \& Agassiz, 1829) & Characiformes \\
Cachorro & Rhaphiodon vulpinus Spix \& Agassiz, 1829 & Characiformes \\
Caparari & Pseudoplatystoma punctifer (Castelnau, 1855) & Siluriformes \\
Cara de gato/coroatá & Platynematichthys notatus (Jardine, 1841) & Siluriformes \\
Cuiu-cuiu & Oxydoras niger (Valenciennes, 1821) & Siluriformes \\
Curimatã & Prochilodus nigricans Spix \& Agassiz, 1829 & Characiformes \\
Dourada & Brachyplatystoma rousseauxii (Castelnau, 1855) & Siluriformes \\
\hline
\end{tabular}




\begin{tabular}{|c|c|c|}
\hline Filhote & Brachyplatystoma filamentosum (Lichtenstein, 1819) & Siluriformes \\
\hline Gogo & Brycon melanopterus (Cope, 1872) & Characiformes \\
\hline Gurijuba & Aspistor luniscutis (Valenciennes, 1840) & Siluriformes \\
\hline Jandiá & Leiarius marmoratus (Gill, 1870) & Siluriformes \\
\hline \multirow[t]{2}{*}{ Jaraqui } & Semaprochilodus insignis (Jardine, 1841) & Characiformes \\
\hline & Semaprochilodus taeniurus (Valenciennes, 1821) & \\
\hline Jatuarana & Brycon amazonicus (Spix \& Agassiz, 1829) & Characiformes \\
\hline Jau & Zungaro zungaro (Humboldt, 1821) & Siluriformes \\
\hline Jiju/ jeju & Hoplerythrinus unitaeniatus (Spix \& Agassiz, 1829) & Characiformes \\
\hline Mandi & Pimelodus blochii Valenciennes, 1840 & Siluriformes \\
\hline Mapará & Hypophthalmus marginatus Valenciennes, 1840 & Siluriformes \\
\hline \multirow[t]{2}{*}{ Matrinxã } & Brycon amazonicus (Spix \& Agassiz, 1829) & Characiformes \\
\hline & Brycon falcatus Müller \& Troschel, 1844 & \\
\hline \multirow[t]{2}{*}{ Pacu } & Mylossoma duriventre (Cuvier, 1818) & Characiformes \\
\hline & Mylossoma aureum (Spix \& Agassiz, 1829) & \\
\hline Peixe lenha & Sorubimichthys planiceps (Spix \& Agassiz, 1829) & Siluriformes \\
\hline Pescada & Plagioscion squamosissimus (Heckel, 1840) & Perciformes \\
\hline \multirow[t]{3}{*}{ Piau/aracu } & Megaleporinus trifasciatus (Steindachner, 1876) & Characiformes \\
\hline & Leporinus fasciatus (Bloch, 1794) & \\
\hline & Schizodon fasciatus Spix \& Agassiz, 1829 & \\
\hline Pintado & Pseudoplatystoma corruscans (Spix \& Agassiz, 1829) & Siluriformes \\
\hline \multirow[t]{2}{*}{ Piraíba } & Brachyplatystoma filamentosum (Lichtenstein, 1819) & Siluriformes \\
\hline & Brachyplatystoma capapretum Lundberg \& Akama, 2005 & \\
\hline Piramutaba & Brachyplatystoma vaillantii (Valenciennes, 1840) & Siluriformes \\
\hline \multirow[t]{4}{*}{ Piranha } & Pygocentrus nattereri Kner, 1858 & Characiformes \\
\hline & Serrasalmus rhombeus (Linnaeus, 1766) & \\
\hline & Serrasalmus spilopleura Kner, 1858 & \\
\hline & Pristobrycon striolatus (Steindachner, 1908) & \\
\hline Pirapitinga & Piaractus brachypomus (Cuvier, 1818) & Characiformes \\
\hline Pirarara & Phractocephalus hemioliopterus (Bloch \& Schneider, 1801) & Siluriformes \\
\hline \multirow[t]{2}{*}{ Sardinha } & Triportheus angulatus (Spix \& Agassiz, 1829) & Characiformes \\
\hline & Triportheus elongatus (Günther, 1864) & \\
\hline Surubim/cachara & Pseudoplatystoma fasciatum (Linnaeus, 1766) & Siluriformes \\
\hline Tambaqui & Colossoma macropomum (Cuvier, 1816) & Characiformes \\
\hline Tamoatá & Hoplosternum littorale (Hancock, 1828) & Siluriformes \\
\hline Traíra & Hoplias malabaricus (Bloch, 1794) & Characiformes \\
\hline Tucunaré & Cichla pleiozona Kullander \& Ferreira, 2006 & Cichliformes \\
\hline
\end{tabular}


Cichla temensis Humboldt, 1821

Cichla sp.

Zebra Brachyplatystoma tigrinum (Britski, 1981)

Siluriformes

"SALADA"

Fish species with low commercial value

\section{SUPPLEMENTARY MATERIALS}

Dataset: LIOP_Dataset_desembarque2001-2013.xIsx

\section{ACKNOWLEDGEMENTS}

The authors would like to thank the Fishermen's Colony "Z-31 Dr. Renato Pereira Gonçalves" (Humaitá, AM), the "Laboratório de Ictiologia e Ordenamento Pesqueiro do Vale do Rio Madeira (LIOP)", the "Universidade Federal do Amazonas (UFAM)"; the "Conselho Nacional de Desenvolvimento Científico e Tecnológico (CNPq)"; the "Coordenação de Aperfeiçoamento de Pessoal de Nível Superior (CAPES)", and the "Fundação de Amparo à Pesquisa dos Estados do Amazonas (FAPEAM)", with the "Programa de Apoio à Organização, Restauração, Preservação e Divulgação das Coleções Biológicas e de Museus e de Museus do Estado do Amazonas - COLEÇÕES BIOLÓGICAS/MUSEUS (edital no 008/2019)".

\section{REFERENCES}

AGOSTINHO, A. A.; GOMES, L. C.; VERÍSSIMO, S.; OKADA, E. K. Flood regime, dam regulation and fish in Upper Paraná River: Effects on assemblage attributes, reproduction and recruitment. Reviews in Fish Biology and Fisheries, 14(1), 11-19, 2004. DOI: https://doi.org/10.1007/s11160-004-3551-y.

BARTHEM, R. B.; GOULDING, M.; LEITE, R. G.; CAÑAS, C.; FORSBERG, B.; VENTICINQUE, E.; RIBEIRO, M. L. B.; CHUCTAYA, J.; MERCADO, A. Goliath catfish spawning in the far western Amazon confirmed by the distribution of mature adults, drifting larvae and migrating juveniles. Scientific Reports, 7, 41784, 2017. DOI: https://doi.org/10.1038/srep41784.

GOULDING, R. M. Ecologia da pesca do rio Madeira. CNPQ-INPA, Manaus, Brazil, 1979.

GUYOT, J. L.; JOUANNEAU, J. M.; SOARES, L.; BOAVENTURA, G. R.; MAILLET, N.; LAGANE, C. 2007. Clay mineral composition of river sediments in the Amazon Basin. Catena, 71, 340 - 356, 2007. DOI: https://doi.org/10.1016/j.catena.2007.02.002.

HORBE, A. M. C.; QUEIROZ, M. M. A.; MOURA, C. A. V.; TORO, M. A. G. Geoquímica das águas do médio e baixo rio Madeira e seus principais tributários - Amazonas - Brasil. Acta Amazonica, 43(4), 489-504, 2013. DOI: https://doi.org/10.1590/s0044-59672013000400011.

IBGE. Instituto Brasileiro de Geografia e Estatística. v4.6.6, 2017. Disponível em: $<$ https://cidades.ibge.gov.br/>.

RODDAZ, M.; VIERS, J.; BRUSSET, S.; BABY, P.; HERAIL, G. Sediment provenances and drainage evolution of the Neogene Amazonian foreland basin. Earth and Planetary Science Letters, 239, 57-78, 2005. https://doi.org/10.1016/j.epsl.2005.08.007

ROSA, R. S; LIMA, F. C. T. Os Peixes Brasileiros Ameaçados de Extinção. In: MACHADO, A. B. M.; DRUMMOND, G. M.; PAGLIA, A. P. (eds.) Livro vermelho da fauna brasileira ameaçada de extinção. Ministério do Meio Ambiente, Brasília, Brazil, 2008. 
SANTOS, R. E.; PINTO-COELHO, R. M.; FONSECA, R.; SIMÕES, N. R.; ZANCHI, F. B. The decline of fisheries on the Madeira River, Brazil: The high cost of the hydroelectric dams in the Amazon Basin. Fisheries Management and Ecology, 25(5), 380-391, 2018. DOI: https://doi.org/10.1111/fme.12305.

SNIRH. Sistema Nacional de Informações sobre Recursos Hídricos. Portal HidroWeb v3.2.6., 2021. Disponível em: <https://www.snirh.gov.br/hidroweb/apresentacao>.

TIMPE, K.; KAPLAN, D. The changing hydrology of a dammed Amazon. Science Advances, 3, 1-13, 2017. DOI: https://doi.org/10.1126/sciadv.1700611. 